\title{
Considering change with archaeological data: reevaluating local variation in the role of the
} $\sim 4.2 \mathrm{k}$ BP event in Northwest China

\begin{abstract}
Over the past two decades, environmental studies in research on prehistoric China have been gaining popularity and importance. For Northwest China in particular, climate change, especially the so-called $\sim 4.2 \mathrm{k}$ BP event has been seen as the main reason for an alleged collapse of Late Neolithic societies and a transition to pastoral-heavy economies and mobile lifeways. Yet, these explanatory models tend to rely on limited archaeological and environmental data and non-contemporaneous historical data, resulting in simplistic causal relationships between environmental changes and social response.

This paper re-evaluates the Incipient Bronze Age in China's Northwestern region, discussing evidence for climate change and its exact dates, as well as textual and archaeological evidence. We argue that the old narratives perpetuating the image of a dichotomy between Steppe and Sown are inaccurate, while largescale models of region-wide subsistence change in response to climate cooling tend to disregard local developments and group-specific responses as well as chronological issues. Focusing on the Xindian and Siwa archaeological phenomena, this paper provides a view into sub-regional responses to this climate event, warning against simplistic broad-brush reconstructions and calling for both a return to archaeological fundamentals and large-scale intensive fieldwork and interdisciplinary studies involving archaeologists, paleobotanists, zooarchaeologists, isotope specialists, and climate scientists.
\end{abstract}

Keywords: Climate change; subsistence; Northwest China; Siwa; Xindian; Bronze Age; isotope studies

\section{First/corresponding author: Yitzchak Y. Jaffe}

ORCID - 0000-0002-4114-0910

Affiliation:

The Zinman Institute of Archaeology

University of Haifa

199 Aba-Hushi Avenue

Haifa, Israel 3498838

Tel: +972-587901999

Fax: +972-4-8249876

yiaffe@univ.haifa.ac.il

\section{Second author: Anke Hein}

ORCID - 0000-0002-5052-1504

Affiliation:

Oxford University, School of Archaeology

Institute of Archaeology

36 Beaumont St

Oxford, Oxfordshire, UK OX1 2PG

Considering change with archaeological data: reevaluating local variation in the role of the $\sim 4.2 \mathrm{kPP}$ event in Northwest China 


\section{Introduction}

Environmental studies linking climate change and social transformation in prehistoric China, have been gaining popularity and significance over the past two decades (e.g., Guo et al., 2014; Jia et al., 2018; Zhang et al., 2006). The so-called $\sim 4.2 \mathrm{k}$ BP event has played an important role in this growing body of literature, where it is often seen as a pivotal moment in the development of Chinese civilization (Gao et al., 2007; Huang et al., 2011; Li et al., 2014; Liu and Fang, 2012; Wu and Liu, 2004). The alleged collapse of Late Neolithic societies supposedly triggered by this event is believed to have fostered the creation of the first state in the Yellow River Valley during the subsequent Bronze Age. This development supposedly went hand in hand with radical changes in subsistence strategies - the set of practices employed by a group to obtain food - and socio-political realities of the people living outside of that region (An et al., 2005; Li et al., 2017; Liu, 2000; Liu et al., 2010).

For the northwestern part of modern-day China, namely the provinces of Gansu and Qinghai, climate change has been enlisted to explain a transition to pastoral-heavy economies and mobile lifeways during this period (e.g. Hou et al., 2009; Liu and Feng, 2012). Yet, many of these models of cultural developments and their environmental correlates rely on limited proxies and archaeological data sets, resulting in varying reconstructions of the local groups and their changes over time (see Yang et al., 2019). The ways in which archaeologists have reconstructed the social, political, and economic systems in the Northwest, have been heavily influenced by traditional narratives regarding the non-Han identity of the people inhabiting this region in prehistory (Hu, 1980; Li, 2006; Wang, 2012). In fact, by drawing upon ethnic attributions found in later texts, new environmental models have reinforced old narratives perpetuating the image of a dichotomy between Steppe and Sown and pushing their appearance well into the deep past (see Di Cosmo, 2002 for a discussion of these historical narratives).

This paper aims at reevaluating the incipient Bronze Age in China's Northwest with a critical eye on these models, be they based on (mostly later) historical texts or (rather limited) environmental and archaeological data. We argue that blanket statements have been made that subsume local variations in the aftermath of the so-called $\sim 4.2 \mathrm{k}$ BP event. We focus on the Xindian and Siwa archaeological cultures as they provide a window into sub regional responses to this climatic event. Found mainly the modern province of Gansu, these cultures have often been seen to have undergone changes in economic strategies that let them to practice more intensive pastoralism and even nomadism. Unlike the areas directly to their north, namely the Hexi corridor and Eastern regions of Xinjiang, where recent application of stable isotopic analysis has been conducted to better understand the relationship between diet and climate change, this part of Gansu has seen only partial archaeological work. However, even with the limited archaeological data that exists for Siwa and Xindian cultures, much can be said about what did not happened in light of the so-called $\sim 4.2 \mathrm{k}$ BP event. To do so we provide an overview of related developments in archaeological research over the past two decades and new approaches to its study and analysis. By showing stability and resilience among these communities, we question the simplistic causal relationships between environmental changes and social responses assumed in much recent research.

\section{Climate and social transformation in Northwestern China during the $4^{\text {th }}$ millennium BP}

According to our current knowledge, in the Northwest the Neolithic-period Yangshao material common throughout much of northern China was followed by a localized variety of painted pottery referred to as Majiayao. These wares underwent some stylistic changes commonly grouped into three sub-types, Majiayao, Banshan, and Machang generally interpreted as subsequent phases (Shui, 2001). All of these ceramic types are associated with large sites and a settled agricultural mode of subsistence (Xie, 2002). The subsequent Qijia archaeological cultural phenomenon known for its metallurgy and common throughout Gansu and parts of Qinghai, is also assumed to be agricultural with much evidence for pig 
rearing, while bones of other animals such as sheep/goat, dog, cattle and horses are much less common (Dong et al., 2014; Womack et al., 2017).

Following the fragmentation of the Qijia (roughly 2300-1500 BCE and see Jaffe and Flad 2018), a number of different ceramic traditions sprang up during the Second and First Millennia BCE (Table 1). These different ceramic types have been the basis for defining the archaeological cultures of Siba (1900-1500 BCE) and Kayue (1600-700 BCE) in the northern parts of Gansu and Qinghai, and the Xindian (1600-600 BCE) and Siwa (1400-700 BCE) in the Center and Eastern part of Gansu (Womack et al., 2017). Both Xindian and Siwa are believed to have derived directly from Qijia and to have continued to influence each other over time (Li et al., 2010; Wang, 2012), however, the nature of this supposed connection between Siwa and Xindian is not clear and based solely on sporadic finds of items stylistically assigned to one culture in sites of the other (e.g., Nan, 1989; Rawson, 2013; Xie, 2002; Zhongguo, 2006).

Table 1. Major archaeological cultures in Northwest China and their dates (after Womack et al. 2017)

\begin{tabular}{|l|l|r|}
\hline Culture & Phase & Approximate Dates BCE \\
\hline Yangshao & & $5000-3000$ \\
\hline Majiayao & & $3300-2650$ \\
\hline & Banshan & $2800-2300$ \\
\hline & Machang & $2300-1950$ \\
\hline Qijia & & $2300-1500$ \\
\hline Siba & & $1900-1500$ \\
\hline Kayue & & $1600-700$ \\
\hline Xindian & & $1600-600$ \\
\hline Siwa & & $1400-700$ \\
\hline
\end{tabular}

A number of related issues, including long-held historical narratives, have shaped Bronze Age Gansu archaeological scholarship. Firstly, this region traditionally has been considered peripheral to the central formation of Chinese civilization (Li et al., 2010; Shui, 2001). Wang Hui's (2012) survey of the cultural development of the Tao River Valley is a prime example: for the period prior to the $2^{\text {nd }}$ millennium BCE, Wang refers to the Neolithic cultures inhabiting this region as a variant of early Chinese culture, while in the $2^{\text {nd }}$ millennium, with the Xia, Shang, and Zhou firmly established in the Central Plains, he does not consider archaeological cultures in the West to be part of ancient Chinese civilization anymore. He sees their return into the larger Chinese cultural milieu only when the Qin conquest brings them under direct rule, a task completed more fully by the Han period in the late last millennium BCE and the early first millennium CE.

Secondly, publications discussing the Siwa and/or Xindian often link them to the so-called "barbarian tribes" mentioned in historical texts who lived alongside these "Chinese" states, but in regions peripheral to the early Chinese dynasties in the Central Plains. Some view the Siwa culture's earlier variant as linked to the Qiang, while the later variant they see as identical to the Rong mentioned in later historical texts (Hu, 1980:123-124; Zhao, 1989; Zhongguo, 2006:96). Ohers have identified Xindian with the Qiang tribes (Wenwu, 1979; Xie, 1985; and see Cheung et al., 2017a). Furthermore, given the prominence the archaeological cultures of the Central Plains enjoy within archaeological debates in China, the societies inhabiting outlying regions such as the Northwest are often seen as inferior, passive receivers of cultural influences coming from the "core" of Chinese culture on the one hand (Jun, 2004; Lu, 2013; Zhao, 1989) and mere transmitters of innovations from further west such as bronze technology and new domesticates such as wheat and barley on the other. 
What feeds into these views, and even demands that the Siwa and Xindian be considered an 'Other' to the Chinese in the East, is the notion that the inhabitants of these regions practiced pastoralism - often seen as exclusively so - as an important component of their economy rather than being settled agriculturalists like the inhabitants of the Central Plains. In the Northwest, pastoralism is believed to have replaced the dominant rain-fed agricultural economy focused on millet that was practiced throughout the $3^{\text {rd }}$ and $2^{\text {nd }}$ millennium BCE (Li et. al., 1993; Shui, 2001; Xie, 2002; Xu, 1988).

In recent years, arguments for a dominant pastoral subsistence base - i.e. a diet heavily reliant on animal derived foods - for the inhabitants of the northern zone have been bolstered, allegedly, by environmental studies that view the aftermath of climatic events in the late $3^{\text {rd }}$ millennium BCE as demanding this shift. Linking the $\sim 4000$ cal. BP climatic event (aka the $4.2 \mathrm{k}$ BP event) to cultural changes is a recurring theme in the reconstruction of socio-cultural change in ancient China. Scholars have argued that during the Holocene a number of global climatic fluctuations occurred. The $\sim 4.2 \mathrm{k} B P$ event, one of the most dramatic of these changes, is characterized by mostly cooling at upper latitudes and drying at the middle and lower latitudes (Mayewski et al., 2004; Paasche, 2009; Wanner et al., 2011) or simply as 'dry north and wet south' (e.g., Tan, 2018). In Northern China, Inner Mongolia, Qinghai and Gansu, the added aridity is believed to have resulted in the collapse of many of the existing societies and the eventual transition from agriculture to a heavily reliance on pastoral economies and even limited nomadism (An et al., 2005;2010; Hou et al., 2009; Liu and Feng, 2012; Wu and Liu, 2004).

It is important to point out that a great deal of disagreement and debate exists in the paleoclimatic literature regarding the so called $\sim 4.2 \mathrm{BP}$ event (see recent overview in Rousseau et al., 2019), including the nature and location of its impact in China (e.g. Arz et al., 2015; Goldsmith et al., 2017; Maher, 2008), the actual change it brought about (i.e. cold and dry or warm and wet) as well as internal variations during this period (e.g. Li et al., 2014; Zhang et al., 2018) and the dating of this event, its start, duration and end (e.g. Jones et al., 2016; Nakamura et al., 2016, Railsback et al., 2018 and see overview in Jaffe et al. forthcoming).

Consequently, contrary to views espousing widespread socioeconomic changes throughout Northwest China, we argue that as the precise dates of many of the archaeological cultures in this region are still debated, any proposed direct impact by a given climate event on these societies needs to be demonstrated rather than assumed (Blaauw, 2012; Butzer and Endfield, 2012; Carelton and Collard, 2019; Izdebski et al., 2016; Jaffe et al., 2019; Kintigh and Ingram, 2018; Xopalki et al., 2016). In other words, before we can establish causality between climate events as bringing about the collapse of Qijia agricultural communities and the subsequent transition towards nomadic pastoralism, we need to establish correspondence between these data sets. This is to say that given the disagreement over chronological schemes, it may turn out that the $\sim 4.2 \mathrm{k}$ BP event happened before or after the end of the Qijia period and the emergence of ceramic facies that characterized different archaeological cultures in subsequent periods (for the most recent dates consult Brunson et al., 2020; Dittmar et al., 2019; Jaffe and Flad, 2018; Womack et al., 2017). Indeed, there is considerable debate on all of these dates as they are based mostly on typo-chronological assessments on ceramics excavated from graves, combined with very limited stratigraphic evidence from settlement sites and even fewer radiocarbon dates. For Qijia, for instance, beginning dates cited by different scholars range from 2,300 to 2,100 and the end dates range from 1,900 to 1,500 (e.g., Chen, 2013; Wang, 2012; Xie, 2002), with recent radiocarbon dates suggesting later end dates (Brunson et al., 2020).

Many of the studies cited above are faced with other constraints that render the acceptance of causal relationships between climate change and social action problematic. For instance, most of the 
archaeological data utilized in these studies geared to show impacts of climate events on human societies are derived from the Chinese Cultural Relics Atlases, a series whose volumes are published separately by province. In these recent papers, the sites documented in the atlases are tabulated to show a decline in total numbers of archaeological sites as well as changes in their location in the landscape (e.g. Guo et al., 2014; Liu and Feng, 2012; Wagner et al., 2013). For example, Hosner et al. (2016) argue for a dramatic drop in the number sites post 2000 BCE and Dong et al. (2013a and 2013b) suggest that the Kayue, whom they see as an ethnic group, migrated to higher altitudes where lower temperatures were the norm.

However, there are several critical issues with the Atlas data that make their use limited (see Jaffe et al. forthcoming for a detailed overview). The data compiled in them are a combination of the results of the first and second National Cultural Relics Survey (1956 and 1981-1989 respectively) and further field research conducted since. The surveys underlying these data have often focused on locations were people had reported finds or where finds were expected to occur (such as in particularly fertile river valleys). The data collected in these volumes therefore cannot accurately reflect past preferences in settlement location. Furthermore, the majority of these sites remain unexcavated and their date has been assessed solely on the basis of a small number of sherds found on the surface. Additionally, treating all binary reporting of a site assigned to a certain archaeological culture and/or period as reflecting equal human activity without paying attention to the type and intensity of finds is highly problematic, again, making reconstructions of actual socioeconomic dynamics difficult (see McCoy, 2017). Indeed, one can hardly reconstruct sociopolitical organization, ethnic identity or political affinity on the basis of ceramic styles alone, and the identification of ceramic styles and identity groups is highly problematic as well (Hein, 2016). While ceramics are the most ubiquitous type of finds and can be used in typochronologies for assessing changes over time and differences between various regions and groups, archaeological cultures thus defined should not be equated with cultures in the broader sense of identity groups, let alone peoples or ethnic groups. Accordingly, we cannot assume that all sites sharing the same ceramic styles necessarily practiced the same form of subsistence - something that can only be shown through carful excavation of residential contexts at each individual site.

We are not the first to call for caution when discussing the connection between subsistence systems and climate change. Following a growing number of papers finding a post 1600BCE date for the development of wheat and barley agriculture in this and adjacent regions (e.g., Atahan et al., 2011; Flad et al., 2010; He et al., 2017; Lee et al., 2007; Li et al., 2007; Ma et al., 2014), the causal relationship between the so-called $\sim 4.2 \mathrm{k} \mathrm{BP}$ widespread event and local socio-economic responses is being reevaluated. For instance, Yang et al. (2019) have recently argued for a mixed relationship between climate change and social outcomes throughout prehistoric China. While most of the above work has focused on the Hexi corridor in the north and implications of their results for the societies inhabiting it, healthy skepticism should be extended to include the Xindian, Siwa, and other archaeological cultures to the south - particularly when we remember that they post-date the $\sim 4.2 \mathrm{kBP}$ event by at least half a millennium into the $1^{\text {st }}$ millennium $B C E$.

In most of these studies pastoralism remains poorly defined beyond a mention of a decrease reliance on grains (such as millet) and the raising of sheep/goat or cattle, as opposed to pig husbandry and intensive agricultural production (though long range herding and increased mobility are often implied e.g., Jaang, 2015; Wu and Liu, 2004). Numerous scholars have challenged the application of wholesale nomadic pastoralism onto past societies and argue that these are later developments (see in Jaffe, 2020). Furthermore, pastoral economies encompass a wide range of herd management strategies, mixed with agricultural reliance and sedentary preferences (Arbuckle and Hammer, 2018; Honeychurch and Makarewicz, 2016). The actual relative proportion of grains, animals and their products, as well as other aspects of the societies in question, including the built environment, must be taken into account. Carful excavation of domestic settings and analysis of ceramic and lithic assemblages, coupled with robust 
zooarchaeological and paleobotanical studies provide the best methodology to ascertain subsistence practices (e.g., Marom et al., 2019; Shelach, 2009; Bogaard et al., 2017). In fact, recently, with the introduction of stable isotope analysis, a complicated picture has begun to emerge where grains remained important, but with varying degrees, among the many different communities that inhabited this region during the $3^{\text {rd }}$ and $2^{\text {nd }}$ millenniums BCE (and see discussion section below).

Finally, we point out the complex issue of historical framing that has influenced the reconstruction of communities inhabiting the region. These reconstructions tend to be a product of the projection of more recent historical periods onto the deeper past: a heavy reliance on pastoralism characterized the economy of people inhabiting these region during later periods, such as the Xiongnu ( $3^{\text {rd }} \mathrm{c}$. BCE to the late $1^{\text {st }} \mathrm{C}$. CE) who did, in fact, practice nomadic pastoralism, and whose mobility was a defining factor of their social and cultural organization (Brosseder and Miller, 2011). Later historical texts such as the Shiji or Hanshu reported that these regions were inhabited by non-Huaxia people demarcated by differing subsistence practices namely pastoral nomadism. Inadvertently, several of the abovementioned studies anachronistically project later historical realties onto the deeper past, realities that further structure the nature of interactions between these societies as well (and see Bunker and Arthur, 1997; Di Cosmo, 2002; Shelach, 2009). Shui (2001:276-283), often cited as a key study on the economic nature of early societies in Northwest China, has actually warned that we should not attempt to equate the Siwa, Xindian, or Kayue with the Qiang or Rong barbarians mentioned in historical accounts, noting that these terms were generic enthnonyms in the sense that they were used to describe the multitude of peoples that existed to the West of the Zhou. Indeed, there is the additional problem that the historical texts in question are of considerably later date than the archaeological evidence in question, and were furthermore written by people located in the Central Plains with no direct evidence of how people in Northwest China lived.

In sum, the combination of a strong historical narrative complemented by approaches equating ceramic styles with bounded ethnic groups inhabiting this region have produced decades of preconceived notions regarding the sociopolitical relates in Gansu. Rather than challenge these narratives, the introduction of climate science has, to date, mostly bolstered these reconstructions by supposing perceived wide-scale impacts of global climate events. What has yet to be reevaluated, and is indeed often overlooked in many of the studies cited above, is the archaeological data itself. Below, we overview two major archaeological cultures that have played a prominent role in the hypothetical post $\sim 4.2 \mathrm{k}$ BP collapse and transition to pastoralism, Siwa and Xindian (for a comparable study on the earlier Qijia culture which spanned this period see Jaffe et al. forthcoming). In doing so we highlight the importance of evaluating the localized data when addressing the impacts of large-scale events such as the case of the $\sim 4.2 \mathrm{k} \mathrm{BP}$ event.

\section{The archaeological evidence}

Prior to the work of the Swedish geologist Johan Gunnar Andersson in the early $20^{\text {th }}$ century, very little was known about the Chinese Neolithic, and Northwest China had not yet been explored archaeologically. When he encountered high-quality painted pottery during his work in Henan, European archaeologists suggested to him that these were the outcome of migration from Eastern Europe (Andersson, 1925; Fiskesjö and Chen, 2004). During work conducted in 1923-24, Andersson discovered a large number of settlement and grave sites characterized by hitherto unknown types of pottery. Based on a combination of stratigraphy and ceramic typology, he defined a number of new archaeological cultures and suggested a first chronology for the region (Andersson, 1943). The chronology soon had to be revised, however, as Andersson had erroneously placed Qijia at the beginning of the local cultural development. That chronology was soon challenged and corrected by Xia Nai (1961), and the absolute dates had to be adjusted throughout subsequent periods, however, the culture names established by Andersson are mostly still in use today, albeit with dates that have been adjusted again and again based on new finds and scientific dates (Table 1). 
Subsequent decades have mostly seen salvage archaeology overseen by the Gansu Provincial Institute of Archaeology, punctuated by bursts of intensive fieldwork on various occasions (Shui, 2001; Wang, 2012). The latter have focused on regional surveys following important waterways (e.g., Gansusheng et al., 2008) and the systematic excavation of cemeteries (e.g., Zhonguo, 2006). Shui Tao's (2001) work is most often cited as providing archaeological support for the existence of pastoral economies in the Northwest during the second millennium BCE. In the late Qijia period, Shui (2001:291) argues, there might have been a shift toward a pastoralist economy as the increase of sheep/goat bones at sites of that period suggests. Yet, as there is very little evidence and all of it from graves, this view is not universally accepted (Shelach 2009:50). Siba, now also referred to as Huoshaogou culture, overlaps chronologically with Qijia but is located further west, mostly in the western part of the Hexi corridor, and is known for millet agriculture and pig rearing as well, but also animal husbandry and metallurgy (Chen, 2012; Shui, 2001). Partially based on the lack of plant remains at related sites, Shui (2001:291-4) argues that Siba as well as the later archaeological phenomena of Xindian, Siwa, and Kayue had a pastoralist economy. About Kayue, very little is known and only very few sites are assigned to this archaeological culture.

In the present paper, therefore, we concentrate on the better-documented archaeological phenomena of Siwa and Xindian (see Table 2 and Figure 1). As they are found mostly in Gansu province focusing on these archaeological cultures further provides a sub-regional inspection into the aftermath of the widespread $\sim 4.2 \mathrm{k}$ BP event in Northwest China. Below, the data for each of them is discussed in turn, paying particular attention to evidence that allows for inferring subsistence patterns. These come from brief and full site reports (where available) published as full manuscripts or journal entries (for an overview of the differences between these data types see Selbitschka 2018). Together they represent nearly all available published excavated and systematic survey work on the Siwa and Xindian archaeological cultures (for a recent survey of all mentioned Siwa archaeological material found and reported see Yang 2013; for a study of the Qijia culture in light of the $\sim 4.2 \mathrm{k} \mathrm{BP}$ event and the many problems with using atlas data see Jaffe et al. forthcoming; for an overview of Xindian material see Jaffe et al. accepted).

\section{Siwa}

The Siwa archaeological culture was defined by Andersson based on the ceramics found in graves at Siwashan in Lintao County, most striking among them double-handled jars with saddle-shaped openings (Figure 2) that came to be seen as characteristic for Siwa (Andersson 1925). Andersson assigned them to the fifth culture phase in his six period prehistoric sequence of the region (Andersson 1943: 179-185). Subsequent work by Xia Nai (1949) lead to the conclusion that the Siwa Culture was native to Gansu, and that the saddle-shaped mouth jar was a development based on of the ceramic styles of the Machang and Banshan phases of the Majiayao (3300-1950 BCE) painted pottery tradition combined with later Xindian influence.

Following survey work in the 1950's and 1960's, the Siwa archaeological culture was further separated into two variants: the older Siwashan variant and a new 'Anguo style' pottery tradition (Gansu, 1960:22), but most scholars simply refer to all remains and sites collectively as Siwa. The majority of pottery is plainware, unpolished and undecorated, but some added plastic ornamentation (appliquè) is known as well. Several vessels are decorated with inlaid stones and beads. Among Siwa assemblages, painted ceramics are rare, while they are common in the contemporaneous Xindian or the earlier Majiayao culture (Shui, 2001:220-221). Pottery was made by slow wheel and often necks and handles were added (Xie, 2002:1934). The surface is often spotted with color imperfections such as fire clouds. The saddle-shaped mouthed vessels account for the vast majority of all vessels found at Siwashan and Anguo sites and are the defining feature of all Siwa material (Xie, 2002:193). In reality, excavated Siwa period sites are mostly cemeteries and all archaeological date are found in funerary contexts. 
Sites with Siwa-type ceramics are mostly located in the Tao River Valley and around the modern-day Gansu provincial capital of Lanzhou. At the Mogou cemetery (better known for its Qijia period burials), excavations in 2009 revealed 21 Siwa graves (Gansu and Xibei, 2014). Unlike the Qijia graves that were arranged in orderly rows, the Siwa tombs are scattered throughout the cemeteries, some cutting into earlier Qijia graves. They exhibited considerable variations in shape and form, number of grave goods, types, their style, the number of individuals interred in them, and how individuals of different age and gender where treated. Metal artifacts are quite rare and limited to ornaments such as earrings and bracelets (Gansu and Xibei, 2014:34-38).

Variation was very much the norm, both in and between sites a fact further calls into question the idea that the Siwa were a single ethnic group who shared an overarching cultural framework that bound them together. Even community-specific mortuary practices were not adhered to by all, resulting in a situation where some cemeteries displayed great variation. The Siwashan cemetery exhibited signs of cremation burial practices alongside inhumation, while at Zhanqi graves display uniform burial patterns, all of them inhumations (Gansu, 2012). All graves are rectangular in shape, most have a stepped platform secondlevel ledge with artifacts placed on them while others are fashioned with niches directly above the head of the interred. The vast majority of tombs are single burials where the deceased was placed in an extended supine position. Many skeletons were dismembered, suggesting that secondary burial practices were common (Gansu, 2012:37).

At Lanqiao, nine rich graves were placed side by side (Gansu et al., 1987). Some graves displayed evidence for intentional removal of skulls or upper limbs - leading the excavators to speculate on the importance of secondary burial practices for this community as well. Several white stones were found in the upper fill of these graves, which might have been placed there by the mourners as graves markers (Gansusheng et al., 1987:670). Of note are a number of unique carvings. Possible connection to Chinese script is unclear, though some similarities to characters known from the Late Shang dynasty capital are noted (Gansu et al., 1987:682).At Jiuzhan, located on the upper tributaries of the Jing River, over 100 graves have been excavated along with two horse and chariot pits (Wang and Shui, 1997). The cemetery spanned several hundreds of years ( 1400-700 BCE), but retained a fairly uniform burial style through its use. All graves were rectangular and shallow with only a few ceramic vessels placed as funerary offerings. Although Western Zhou type ceramics were found alongside Siwa pottery in the residential area (Wang and Shui, 1997:326), they were almost nonexistent in the cemetery, which was dominated by jars with saddleshaped opening. In contrast, at Xujianian, Western Zhou style pottery were part of the mortuary assemblage, as were Zhou style Bronze weapons (Zhongguo, 2006:40, 69-76). Over a 100 graves have been excavated along with two horse and chariot pits. The burial practices at the site were far from uniform, graves varied widely in terms of their shape, grave goods quality and quantity, the number of individuals interred in them and how they were laid to rest (Zhongguo, 2006).

Siwa residential remains are rare - quite possibly the result of where archaeologists have focused their attention (namely the excavation of graves and cemeteries), rather than on actual reflection of architectural preferences of these communities. At Zhanqi, two structures have been unearthed: F1, the better persevered of the two, is a rounded semi-subterranean structure with a hearth and several post holes. The doorway faces north and is roughly $1 \mathrm{~m}$ wide at the base, with a large stone slab adorning it. The earthen floor is tightly packed and might have been created using the rammed-earth technique (Gansu, 2012:39). Structure F2 is not as well preserved and is irregular in shape. There is a single post hole that survived, and the floor yielded remains of textile and pottery patterns pounded into its surface (unfortunately no image has been published). Along with 10 waste pits, two ritual installations were found at the residential part of the site as well - not all of their contents reported on (Gansu, 2012:40). 
Nearby, at the site of Ya'er, two large trash pits provide some of the best preserved residential material of all excavated Siwa sites (Gansu, 1994). Alongside a large number of ceramic sherds, several bone tools were unearthed including shovels, awls, needles, ploughs, adzes, and chisels. Stone tools found at the site comprise mainly polished axes, hammers, knives, and scrapers. Larger tools include grinding stones, mortars and stone hoes. No bronze artifacts were found, but evidence for fabric and cloth production is evidenced by ceramic and stone spindle whorls (Gansu, 1994:21).

Similarly, at Jiuzhan, the residential areas contained domestic stone tools such as hammers, axes, and knives, and one ceramic vessel base contained an imprint of grains. A number of sheep, goat, horse, and cow bones were found as well (Wang and Shui, 1997:333-334), pointing to a sedentary, but mixed agricultural system, however, as no further zooarchaeological research has been conducted, it remains unclear if these bones are from domesticated or wild forms. In addition, four ceramic kilns were excavated, as were stone and ceramic spindle whorls and bone awls, reflecting developed ceramic and textile production (Wang and Shui, 1997:334-336). Additionally, a short part of a stone slab-lined ditch, possibly a water drainage system, was unearthed (Wang and Shui, 1997:310).

At Xujianian, the habitation portion of the site covered at least $10,000 \mathrm{~m}^{2}$ and consisted mainly of broken and damaged ash pits found under houses in the modern village; these, however, were not excavated as the team quickly diverted its attention to the cemetery (Zhongguo, 2006:3-8). Rudimentary zooarchaeological work on the Xujianian cemetery found taxa of sheep/goat cow, horse, and pig (Zhonggou, 2006:238-244). The most common animal found were cattle ( $>85 \%$ of all remains) and not sheep/goat as had been expected. Although this pattern reflects mortuary customs and not diet and everyday subsistence practices, it shows the importance of cattle to the communities in question. Considering this together with the presence of pig remains, the evidence points to domestication at least of these two types of animals rather than a reliance on sheep/goat or hunting for meat procurement.

\section{Xindian}

Sites ascribed to the Xindian culture are located mostly in southern Gansu along the Tao and Daxia Rivers and in the Huangshui River Basin in Qinghai. Based on a combination of typo-chronology and radiocarbon dates, it is now conventionally dated to $1600-800$ BCE (Ren 2019). ${ }^{1}$ The Xindian culture was given its name by Andersson after the discovery of a new ceramic facies at the site of Xindian, Lintao County, Gansu Province in 1924. Soon, a number of other sites with similar ceramics came to light, all of them in the Tao River Valley (Andersson, 1925:14-18). Since then, however, there have only been a limited number of new discoveries revealing similar pottery, and until the present day the distribution of Xindian ceramics and the lifestyle of their producers and users are poorly understood.

Typical ceramic forms comprise double-handled jars of varying proportions, single-handled cups, stemmed or small-eared cups, vases, bowls, and three-legged li vessels (Figure 3). The latter are usually marked with cord impressions while the other vessel types often carry black or black-and-red geometric motives, on very coarse reddish-brown bodies with large crushed rock and/or grog inclusions (Hein and Stilborg, 2019). Typical patterns include triangles, meander bands, mustache-like double-hook/horn shapes, and interlocking T-shapes. Sometimes the rims are decorated with fingertip-impressed appliqué bands. The black or black-brown paint is often applied over corded ware and/or purple, white, orange, or red slip. The patterns are often arranged in decorative bands, mostly horizontal ones on the upper part of the vessels but sometimes joined by vertical ones on the lower part. Additionally, some vessels show stick

\footnotetext{
${ }^{1} \mathrm{~A}$ considerable number of radiocarbon dates have been provided in recent scientific papers, however, most of them do not say how the samples were taken and there are no reports of systematic excavation at those sites. Consequently, the association between the dates and Xindian remains requires further coraboration (e.g., Dong et al., 2014). See Hou et al., (2012) for an exception.
} 
figure-like paintings of birds, dogs, people, and sun symbols usually arranged in between the 'mustaches' or other broad-stroked decorations on the vessel shoulders.

The Xindian-style wares differ markedly from all other ceramics in Gansu in ceramic quality and to a certain extent in decoration motifs. Andersson saw this ceramic tradition as having developed from the Machang tradition (Andersson, 1943:217). Soon, however, the sites of Zhangjiazui and Wujia were discovered where Xindian material was found in cultural layers above Qijia remains, showing that there was a considerable temporal gap between Machang and Xindian (An, 1956). Therefore, some scholars have suggested that Xindian derived from the Qijia ceramic tradition (Nan, 1989), however, recent research has shown that the Xindian material differs markedly from the Qijia ceramics not only in ceramic decoration but also in ceramic quality and pottery technology (Hein and Stilborg, 2019). We have to keep in mind, however, that these changes over time are but that, changes in ceramic style and technology that are not to be equated with population changes. The same applies to the various ceramic sub-styles that are being debated for the Xindian archaeological phenomenon.

Another point of contention is the division of Xindian into several sub-groups. The discovery of Zhangjiazui and Jijiachuan sites in 1947 revealed ceramics similar to material from Xindian and Huizuiwa, yet having particularities of their own. Based on ceramic typology, most scholars distinguish between three different sub-types named after the sites where they were first found and described, Shanjiatou (in the upper Yellow River, Tao River, and Xia River Valleys, in both Gansu and Qinghai), Zhangjiazui (succeeding Shanjiatou in the same area), and Jijiachuan (spread even further and originating in the Wei River Valley in Shaanxi) (Xie, 2002). Ren has recently proposed that Shanjiatou is actually a different culture from which Xindian developed (Ren 2019), however, this is not widely accepted at present. These controversies are of yet unresolved, at least partially because of the limited number of sites and lack of new evidence (discussions in An, 1999; Ren, 2016; Yan, 1978).

The number of sites with Xindian-type ceramics is limited, and excavations (of various intensity) have been conducted at some 10 sites in Gansu and four sites in Qinghai. Most archaeological work has focused on grave sites, identifying a burial tradition that involved simple rectangular NE or SW oriented pits, some with coffins and/or second-level ledge. Others consisted of complex multi-chamber catacomb structures (Qinghai, 1995). The dead were interred facing upwards with their hands placed on the abdomen. In rare cases, secondary burials were observed involving for instance the interment of multiple individuals in one pit, some of them with their skull missing, e.g., at Lianhuatai (Gansu and Beijing, 1988) and Yatou (Gansu, 1981). There are also some multiple burials at Lajia, though their identification as Xindian graves is debated (Minhexian 2015; Ren 2017). Most graves contained several ceramic vessels, commonly doublehandled jars, sometimes with stone or bone tools and/or animal bones, as well as considerable numbers of personal ornaments such as stone beads, bone and metal buttons, and other ornaments, as well as a few bronze knives and awls.

As to settlement sites, most have only yielded surface scatters and numerous trash pits (Zhongguo, 1980b:297-8). So far, only two structures have been documented, both at Jijiazhuang, the better preserved one being a semi-subterranean rectangular building of $5 \times 3 \mathrm{~m}$ with a ramped doorway to the east, several postholes, a lime-plastered floor, a hearth, and remains of waddle-and-daub walls (Zhongguo, 1980a:205-6). Recent excavations at Lajia furthermore have furnished information from seven trash pits (Qinghaisheng et al. 2019). Both house remains and trash pits contained a wide range of different ceramic vessel types, a small number of bone tools, and a considerable number of animal bones. The ceramic types observed in settlement and grave sites are largely identical, but graves lack the large number of tools found in some of the settlement sites, especially the stone artifacts interpreted as agricultural tools. These include bi-faces, axes with long and thin blades deemed to be suitable for tilling earth, as well as mortars and pestles (Zhongguo 1980a:215). 
In recent years, increasingly more paleobotanical and zooarchaeological data has become available. Research in Qinghai showed that sites assigned to the Xindian culture held large amounts of animal bones, especially sheep/goat, the presence of iron fish hooks and nets, and a combination of broomcorn and foxtail millet, barley, wheat, hemp, and other plants, while Qijia sites in the same region were dominated by foxtail millet and pig bones (Zhongguo, 1980a:210-220). This has been interpreted as evidence for a switch from an agricultural mode of subsistence to a mixed economy (Zhang, 2012:28-31). In Gansu as well, Xindian sites have revealed remains of sheep/goat, cattle, pigs, dogs, and horse with sheep/goat being most numerous (Xie, 1985:66). Here, likewise, in-depth analysis on the nature of these remains domesticated vs wild, kill-off patterns, or potential illnesses or injuries - are lacking. The analyses of collagen of herbivore bones from Wenjia in Gansu suggests that domesticated animals may have been fed agricultural crops (Ma et al., 2016:26), however, the current sample size of but two bones is not sufficient for more far-reaching inferences.

Renewed research at the sites of Xindian and Huizuiwa, the first Xindian sites to have been discovered by Andersson, brought new insights into the nature of Xindian settlement sites and the subsistence patterns of their inhabitants (Jaffe et al. accepted). Both sites are relatively small and in elevated, easily defensible locations, but in the case of Huizuiwa used for at least one hundred years. The ceramics from the two sites were very similar in shapes, decoration, and production techniques, however, they seem to differ markedly from sites in other parts of Gansu or Qinghai, suggesting much regional and local variation in ceramic traditions. The faunal remains from Huizuiwa are dominated by sheep/goat but a number of dog bones and remains of wild animals and non-mammals have been found, but in spite of the proximity of the site to the Tao River, fish bones are lacking. The faunal evidence and the find of caprine oracle bones at the site suggest the exploitation of sheep/goat for meat, milk, and possibly wool as well as their importance in ritual activities. The paleobotanical evidence shows a combination of millets and wheat and barley in roughly equal numbers, suggesting that the imported domesticates (i.e., wheat and barley) did not replace millets in importance but were added to the range of grains planted. Paleobotanical and zooarchaeological work taken together suggests that the inhabitants of Huizuiwa practiced an agropastoralist mode of subsistence with both substantial farming and caprine rearing.

Table 2 - Published excavated data for Siwa and Xindian archaeological cultures

\begin{tabular}{|l|l|l|l|l|l|}
\hline Sites & $\begin{array}{l}\text { Excavated } \\
\text { Data }\end{array}$ & $\begin{array}{l}\text { Archaeological } \\
\text { Culture }\end{array}$ & $\begin{array}{l}\text { C14 Dates } \\
\text { (Presented as } \\
\text { reported) }\end{array}$ & $\begin{array}{l}\text { Type of } \\
\text { report }\end{array}$ & Citation \\
\hline Siwashan & $\begin{array}{l}\text { Cemetery, 7 } \\
\text { Siwa graves } \\
\text { excavated }\end{array}$ & $\begin{array}{l}\text { Majiayao/Siwa } \\
\text { (Siwashan) }\end{array}$ & N/A & $\begin{array}{l}\text { Detailed } \\
\text { report in } \\
\text { journal }\end{array}$ & Xia (1949) \\
\hline Mogou & $\begin{array}{l}\text { Cemetery, 21 } \\
\text { Siwa graves } \\
\text { excavated }\end{array}$ & $\begin{array}{l}\text { Qijia/Majaiyao } \\
\text { Siwa } \\
\text { (Siwashan) }\end{array}$ & N/A & Brief report & Gansu and Xibei (2014) \\
\hline Zhanqi & $\begin{array}{l}\text { 60+ Graves } \\
\text { excavated } \\
\text { Several } \\
\text { houses and } \\
\text { pits reported }\end{array}$ & $\begin{array}{l}\text { Siwa } \\
\text { (Siwashan) }\end{array}$ & $\begin{array}{l}\text { 1100-950 cal. BCE } \\
\text { (human bone) }\end{array}$ & $\begin{array}{l}\text { Brief report } \\
\text { mostly on } \\
\text { graves }\end{array}$ & $\begin{array}{l}\text { Gansu (2012) } \\
\text { Chuang (2017b) } \\
\text { Liu et al. (2014) }\end{array}$ \\
\hline Lanqiao & $\begin{array}{l}\text { 9 graves } \\
\text { excavated }\end{array}$ & Siwa (Anguo) & N/A & Brief report & Gansu et al. (1987) \\
\hline Ya'er & $\begin{array}{l}\text { 2 large } \\
\text { Refuse pits }\end{array}$ & Siwa & N/A & Brief report & Ganan (1994) \\
\hline
\end{tabular}




\begin{tabular}{|c|c|c|c|c|c|}
\hline & $\begin{array}{l}\text { Fully } \\
\text { excavated }\end{array}$ & & & & \\
\hline Jiuzhan & $\begin{array}{l}\text { Excavated } \\
80+\text { graves } \\
\text { Reports of } \\
\text { few } \\
\text { structures } \\
\text { and trash pits } \\
\text { as well }\end{array}$ & Siwa (Anguo) & $\begin{array}{l}1375 \pm 155 \text { cal. BCE } \\
\text { (charcoal) }\end{array}$ & $\begin{array}{l}\text { Detailed } \\
\text { report in } \\
\text { journal }\end{array}$ & Wang and Shui (1997) \\
\hline Xujianian & $\begin{array}{l}\text { 100+ graves } \\
2 \text { chariot pits } \\
\text { excavated } \\
\text { Structures \& } \\
\text { trash pits } \\
\text { reported } \\
\text { but not } \\
\text { excavated }\end{array}$ & Siwa (Anguo) & $\begin{array}{l}740-290 \text { cal BCE } \\
\text { (human bone) } \\
\text { * dismissed on basis } \\
\text { of stylistic } \\
\text { typologies }\end{array}$ & Full report & Zhongguo (2006) \\
\hline Xindian A & $\begin{array}{l}\text { cemetery of } \\
100+\text { graves; } \\
20 \text { excavated } \\
\text { by Andersson }\end{array}$ & Xindian & $\mathrm{N} / \mathrm{A}$ & brief report & Andersson $(1925 ; 1943)$ \\
\hline Xindian B & $\begin{array}{l}\text { surface } \\
\text { scatter of } \\
\text { ceramics } \\
\text { attributed to } \\
\text { settlement } \\
\text { remains }\end{array}$ & $\begin{array}{l}\text { Xindian and } \\
\text { Majiayao }\end{array}$ & $\begin{array}{l}\text { charred barley, AMS } \\
\text { dating: } 2908 \pm 42 \\
\text { cal. BP }\end{array}$ & $\begin{array}{l}\text { detailed } \\
\text { report in } \\
\text { journal; } \\
\text { scientific } \\
\text { report }\end{array}$ & $\begin{array}{l}\text { Andersson (1925;1943); } \\
\text { Dong et al. 2016); Jaffe } \\
\text { et al. (accepted) }\end{array}$ \\
\hline Huizuiwa & $\begin{array}{l}\text { settlement } \\
\text { site; one pit } \\
\text { excavated } \\
\text { and reported } \\
\text { in detail }\end{array}$ & Xindian & $\begin{array}{l}\text { charred barley and } \\
\text { wheat: the oldest } \\
\text { sample dates to } \\
2835 \pm 20 \mathrm{BP}, 2 \sigma \\
1047 \text { cal. BCE } \\
\text { (95.4\%) } 925 \text { cal. BCE } \\
\text { (wheat), and the } \\
\text { most recent sample } \\
\text { dates to } 2775 \pm 20 \\
\text { BP, } 2 \sigma 995 \text { cal. BCE } \\
\text { (95.4\%) } 846 \text { cal. BCE } \\
\text { (barley) }\end{array}$ & $\begin{array}{l}\text { detailed } \\
\text { report in } \\
\text { journal; } \\
\text { scientific } \\
\text { report }\end{array}$ & $\begin{array}{l}\text { Andersson (1925;1943); } \\
\text { Jaffe et al. (accepted); } \\
\text { Brunson et al. (2020) }\end{array}$ \\
\hline Zhangjiazui & $\begin{array}{l}\text { settlement } \\
\text { remains }\end{array}$ & Qijia/Xindian & N/A & $\begin{array}{l}\text { excavation } \\
\text { report } \\
\text { (journal } \\
\text { article) }\end{array}$ & $\begin{array}{l}\text { Huanghe (1959); } \\
\text { Zhongguo (1980a) }\end{array}$ \\
\hline Wujia & $\begin{array}{l}\text { settlement } \\
\text { remains }\end{array}$ & Qijia/Xindian & $\mathrm{N} / \mathrm{A}$ & mentioned & Zhongguo (1980a) \\
\hline Shanjiatou & $\begin{array}{l}\text { cemetery, } 33 \\
\text { graves } \\
\text { excavated }\end{array}$ & Qijia/Xindian & N/A & short report & Pei (1987) \\
\hline Jijiachuan & $\begin{array}{l}\text { settlement } \\
\text { remains }\end{array}$ & Xindian & N/A & $\begin{array}{l}\text { excavation } \\
\text { report } \\
\text { (journal } \\
\text { article) }\end{array}$ & Zhongguo (1980a) \\
\hline
\end{tabular}




\begin{tabular}{|c|c|c|c|c|c|}
\hline Lianhuatai & $\begin{array}{l}\text { settlement } \\
\text { remains, } \\
\text { 200+ pits; } \\
\text { cemetery, } 18 \\
\text { graves } \\
\text { excavated }\end{array}$ & Xindian & $\mathrm{N} / \mathrm{A}^{2}$ & $\begin{array}{l}\text { excavation } \\
\text { reports } \\
\text { (journal } \\
\text { articles) }\end{array}$ & $\begin{array}{l}\text { Zhongguo (1980b); } \\
\text { Zhang and Pu (1985); } \\
\text { Gansusheng and Beijing } \\
\text { (1988) }\end{array}$ \\
\hline Yatou & $\begin{array}{l}\text { cemetery, } 3 \\
\text { graves } \\
\text { excavated }\end{array}$ & Xindian & N/A & short report & $\begin{array}{l}\text { Gansusheng (1981); } \\
\text { Ren (2019). }\end{array}$ \\
\hline Xiaohandi & $\begin{array}{l}\text { cemetery, } \\
367 \text { graves } \\
\text { excavated }\end{array}$ & Xindian & $\begin{array}{l}3080 \pm 80 \mathrm{BP} \\
\text { (human bone) }\end{array}$ & $\begin{array}{l}\text { preliminary } \\
\text { report }\end{array}$ & $\begin{array}{l}\text { Qinghaisheng (1995); } \\
\text { Dai (2014); Ren (2019) }\end{array}$ \\
\hline Liuwan & $\begin{array}{l}\text { large } \\
\text { cemetery, } \\
\text { mostly earlier } \\
\text { phases, } 5 \\
\text { Xindian } \\
\text { graves } \\
\end{array}$ & $\begin{array}{l}\text { Banshan,/ } \\
\text { Machang/ } \\
\text { Qijia/Xindian }\end{array}$ & N/A & $\begin{array}{l}\text { excavation } \\
\text { report }\end{array}$ & $\begin{array}{l}\text { Qinghaisheng and } \\
\text { Zhongguo (1984) }\end{array}$ \\
\hline Lajia & $\begin{array}{l}\text { settlement } \\
\text { and graves; } 6 \\
\text { Xindian } \\
\text { graves; } 7 \\
\text { Xindian trash } \\
\text { pits } \\
\end{array}$ & $\begin{array}{l}\text { Qijia/ Xindian } \\
\text { (Shanjiatou } \\
\text { phase) }\end{array}$ & N/A & $\begin{array}{l}\text { excavation } \\
\text { report }\end{array}$ & $\begin{array}{l}\text { Minhexian (2015); Ren } \\
\text { (2017); Qinghai et al. } \\
\text { (2019) }\end{array}$ \\
\hline
\end{tabular}

\section{Discussion}

As we have seen, ideas of a region-wide transition to new economic subsistence systems - i.e., a change from the Qijia period understood to have been one of sedentary grain agriculture supplemented with livestock management, to an increased importance of sheep/goat herding and decreasing reliance on grains during the later Xindian and Siwa - are not clearly supported and are often even contradicted by archaeological finds. To date, very little residential material has been excavated, thus, when lack of evidence of seed crops are mustered to propose a pastoral economy for the Siwa, for instance (e.g., An et al., 2010), such proposals should be treated as hypothetical at best. In fact, for Siwa, what little archaeological evidence we have (the above discussion has provided a near exhaustive overview of all available data) points to an established agriculture-based subsistence pattern as seen as Ya'er, Jiuzhan and Zhanqi - at least one that cannot be said to differ, in any considerable manner, from the previous Qijia period. Some scholars have viewed the Siwa ceramics, characterized by a paste fired at low temperatures and confined to a small repertoire of vessel types, to be indicative of a less developed society inferior to the Zhou, their neighbors to the East (e.g., Li, 2006:176). Yet, work by Jaffe (2016) exploring the technical properties of these vessels finds that the saddle-shaped jars were quite sophisticated and versatile cooking vessels, and in some respects superior to the contemporary li tripods used by the Zhou.

In the case of Xindian, agricultural subsistence is supported by paleobotanical remains, and the rearing of caprines but also other kinds of animals as is reflected in abundant bone remains, as is a moderate amount of hunting. Agriculture and the rearing of domesticated animals thus remained an important part of the subsistence and - in contrast to what has been suggested and shown for parts of the Tibetan Plateau (e.g.,

\footnotetext{
${ }^{2}$ The only $14 \mathrm{C}$ date reported for this site $2540 \pm 120 \mathrm{BP}$ which is generally judged to be problematic (Ren 2019).
} 
d'Alpoim Guedes, 2015, d'Alpoim Guedes et al., 2015) - millet was not replaced by the more cold-tolerant foreign crops of wheat and barley with their lower growing-degree days requirement. This contradicts the assumption that the changes in ceramic assemblages and site locations documented by Siwa and Xindianstyle ceramics went hand in hand with abrupt changes in subsistence patterns that were direct outcomes of dramatic climate changes. The data presented above thus does not suggest that the archaeological phenomena discussed here were dependent on climate events; furthermore, given persistent issues with the absolute dates (e.g., contested dates, old charcoal samples, lack of detailed settlement excavation data with associated absolute dates, missing excavation reports), it is entirely possible that they may not actually have taken place at the same time as these climate changes.

Besides ceramics, stone tools, zooarchaeological, and palaeobotanical research, the introduction of new analytical methods in recent years has provided new data with which to reconstruct the changing diets of ancient communities in prehistoric China. Chief among them is the application of stable isotopes analysis (e.g., Atahan et al., 2011; Barton et al., 2009; Chen et al., 2016; Ma et al., 2014; Zhou et al., 2015; also see overview in $\mathrm{Hu}, 2018$ ). A number of recent studies in the Hexi corridor have argued for a shift in northwestern China from C4 dominated foods to a mixed C3 and C4 diet during the $2^{\text {nd }}$ millennium BCE, though when precisely this process began and how long it took to become the main established mode of subsistence is debated (see Chuang et al., 2019; Dodson et al., 2013; Dong et al., 2017; Flad et al., 2010; Liu et al., 2014; Ma et al., 2016; Zhou and Garvie-Lok, 2016). A rare exception for Xindina and Siwa cultures is work by Cheung et al. (2017b) who looked at a number of individuals from the Siwa site of Zhanqi ( $n=9)$ and Xindian culture site of Lianhuatai $(n=6)$ and found modest $C 4$ consumption at Zhanqi and somewhat higher values at Lianhuatai, as indicated by variations in $\delta 13 \mathrm{C}$ values ( $\delta 15 \mathrm{~N}$ values was similar but due to the lack of local archaeozoological evidence they do not push the interpretation of this marker further). Liu et al.'s (2014) work at Zhanqi found similar isotopic markers and while they do consider the higher $\delta 15 \mathrm{~N}$ to reflect increased meat reliance, they interpret the depleted $\delta 13 \mathrm{C}$ values to indicate a dietary mixture of C4 and C3 plants (although this is based on archaeobotanical findings from other sites).

Old models still exert strong influence in the interpretation of these finds. Some scholars hold that the unfavorable climate changes (the supposed change to dryer and colder realities) led to what they perceive as inescapable outcomes, namely the shift to a mostly pastoral subsistence economy (e.g., Cheung 2019). Others argue that these new environmental conditions demanded the use of new crops, the adoption of wheat and barley, as a way to combat severe cold and low number of growing-degree days that the local millets cannot withstand (e.g., Ma et al., 2016). Others again invoke later historical texts, such as the Shiji and Hanshu, as well as findings of artifacts often associated with mobile pastoralist from further East to argue that pastoralism was the main subsistence strategy in this region (e.g., Yang et al., 2019).

Trying to paint a more nuanced picture, many scholars highlight the importance of establishing isotopic baselines for plants as well as animals, and lament the dearth of systematic zooarchaeological work (e.g., Cheung et al., 2019; Ma et al., 2016; Liu et al., 2014). To be sure, it is quite difficult to adjudicate between competing scenarios where elevated isotopic signatures could indicate direct consumption of plants (C3 or $\mathrm{C4}$ ) or the consumption of animals that were foddered on these plants. In fact, higher values of $\delta 15 \mathrm{~N}$ values, often assumed to indicate a human diet rich in animal protein, are influenced by a host of other factors. These can be climatic changes resulting in higher levels in both plants and animals, intensive agricultural systems using manure, the contribution of marine resources or a smaller amount of legume consumption (An et al., 2015; Bogaard et al., 2007; Huelsemann et al., 2013; Makarewicz and Sealy, 2015; Wang et al., 2018).

Initially, stable isotopes had been proposed as a promising advancement with which to address this issue, precisely because they could be performed independent of traditional paleobotanical and zooarchaeological research and on data sets whose incomplete preservation precluded other types of 
analysis. Yet, overtime, the limitations with regard to scale and ability to interpret isotopic data meant that they had to be informed by zooarchaeological work. Therefore, Makarewicz (2016:198-199) compellingly argues for an integration between zooarchaeology and stable isotopes analyses as well as other disciplines, not only for the purposes of actual use of animal exploitation strategies, but also for establishing adequate statistical samples required for robust stable isotope analysis and calibration of its results given various post-depositional processes.

Consequently, Cheung et al. (2019) note that even when a rise in C3 plants (as compared to C4 plants) during the first millennium BCE is detected, it is difficult to infer which plants are actually involved (rice, barley, or wheat for example), what proportion was gained from direct consumption of these plants or from the consumption of animals foddered on them. Such questions can only be answered with the help of comprehensive paleobotanical and zooarchaeological work conducted on robust domestic contexts combined with a thorough analysis of ceramics and stone tools for evidence of function and usage.

We view the isotope work as as an important effort to squeeze as much information as possible from the limited data sets existing for this region, namely graves, and join the call voiced in these recent papers to expand this type of research, targeting both human bones from burials and animal bones found in graves and settlement sites. Yet, as Thomas and Miller (2018:6) astutely note there is "a general need to better understand the holistic archaeological record, taking into consideration ecological, physiological, and osteological factors that affect both the taphonomy of samples and the reliability of isotope data." Studies that rely on robust, well documented domestic contexts provide vital isotopic bases lines as well as important information on community size, its structures and lifestyles all crucial for the untangling of trophic values from taphonomic preservation issues (Hedges and Reynard, 2007; Pearson et al., 2015; Ren et al., 2017); however, such studies are far and few between or indeed nearly entirely absent for the region and period in question.

A combination of stable isotope analysis with traditional zooarchaeological and other environmental archaeological techniques allows scholars to improve the accuracy and reliability of their reconstruction of relationships between climate-environment, human-environment, and human-animal relationships (see Jones and Britton, 2019). Our call here to expand archaeological research beyond the cemetery is made in light of the limited archaeological data currently available, and pertains directly to the debate revolving around the so-called impacts of climate change in the region. Marom et al. (2019) provide an exemplary study of long-term trends and changes in economy, diet and society in the Negev desert during the Byzantine-Islamic transition (7th-8th centuries CE). Owing to the high-resolution zooarchaeological assemblages from well-studied and intensively excavated residential sites, they are able to delimit social as well as climatically shaped changes in diet and foodways. Pastoralism, often a catch all phrase denoting a wide range of animal management practices, can accordingly be unpacked into not only the overall portion of herd animals raising but also varying degrees of reliance on specific animals (sheep vs goat), as well as consumer preferences of wool/milk/meat (Jaffe et al. accepted).

Certain fundamentals of archaeological research are often missing from the above studies discussed in the paper: lacking any discussion or analysis of residential remains and their relative spatial distribution, the nature of stone tools and traces of use-wear on them, as well as systematic palaeobotanical or zooarchaeological work - let alone residue analysis on ceramic vessels or other research into food preparation techniques. Indeed, while work in the Hexi corridor has seen an increase in isotope, palaeobotanical, and zooarchaeological studies, the areas in which Xindian and Siwa type remains as well as finds of other $2^{\text {nd }}$ millennium BCE archaeological cultures have been found, have yet to even achieve even this level of research. Much field and lab research including large-scale settlement excavations, ceramics research focusing on typology, technology, and residue analysis, isotope studies on human and animal bones from various contexts, systematic floatation and paleobotanical work, systematic 
radiocarbon dating of all contexts, and of course further paleoclimatic research therefore remains to be done before it is possible to investigate potential connections between changes in subsistence systems and known climate events. As such, and in light of the limitations described above, currently we would caution against over- emphasizing the results of stable isotope studies and findings of decreased reliance on grains and a shift to herded animals for Siwa and Xindian archaeological cultures.

\section{Conclusion}

The current archaeological data on the Xindian and Siwa archaeological cultures from modern day Gansu province has shown that there is very little evidence to suggest a sudden (let alone complete) shift in subsistence systems following the so called $\sim 4$.KBP climatic event. Here we have argued that regionalspecific data, both archaeological and environmental are needed if we are to begin understanding the local impacts of this (and other) climatic events. Work by Su and Kidder (2019), for example, has shown that while Shandong and Henan share many of climatic conditions, differences in landscape conditions as well as human cutlrual responses generated different social outcomes. The evidence presented here, namely the Siwa and Xindian archaeological cultures, suggests that the $2^{\text {nd }}$ millennium BCE of modern day Gansu saw a fragmentation and diversification of ceramic styles as well as a continuation of a partially, and in some cases fully, agricultural-based subsistence practices of settled populations. This fragmentation and great variability not only in ceramic styles but also in modes of living including subsistence practices makes clear that sweeping one-size-fits-all explanations trying to explain behavioral patterns for an area as large as Northwest China are hardly adequate. Furthermore, there are still many issues with the local chronology and the correlation (let alone causation) between the climatic event and the changes in material culture, settlement patterns, and subsistence practices is far from securely established.

What is therefore desperately needed at this point is extensive excavation of large areas at numerous settlement sites rather than sample taking from often archaeologically unclear contexts in small test trenches. This is especially needed in Northwest China were non-burial data from the period in question is extremely scarce. Large-scale settlement excavations would provide not only clear correlations between specific ceramic forms and paleobotanical and zooarchaeological samples as well as associated radiocarbon dates, but also new insights into settlement patterns, site organization (including living arrangements and organization of tool and object production and raw-material and food processing and preparation), and social structures. When combined with stratigraphic information, information on ceramic typology and technology, a suitably large number of radiocarbon dates, and robust stable isotope studies these behavioral patterns can then be placed in relation to changes and constants in the local environment and climate.

\section{Acknowledgments}

The authors want to express their thanks to Rowan Flad, Wang Hui, Zhou Jing, and the entire TRAP team for working together on the project, granting them access to material, and discussing their ideas with them. The authors are grateful for the many comments and suggestions of the three anonymous reviewers as well as associate editor Ma Minmin. Their efforts have truly helped in making the paper clear and the arguments in it stronger. Finally, they also want to thank Liu Ruiliang (Ray) for organizing this Holocene special issue and inviting them to contribute.

\section{Figures}






Figure 1. Map of area with Siwa and Xindian sites mentioned in text. 1. Liuwan 2. Lajia 3. Jijiachuan 4.Lianhuatai 5. Zhangjiazui 6. Yaotou 7. Huizuiwa 8. Xindian 9. Xiwashan 10. Zhanqi 11. Mogou 12. Ya'er 13. Lanqiao 14. Xujianian 15. Jiuzhan.

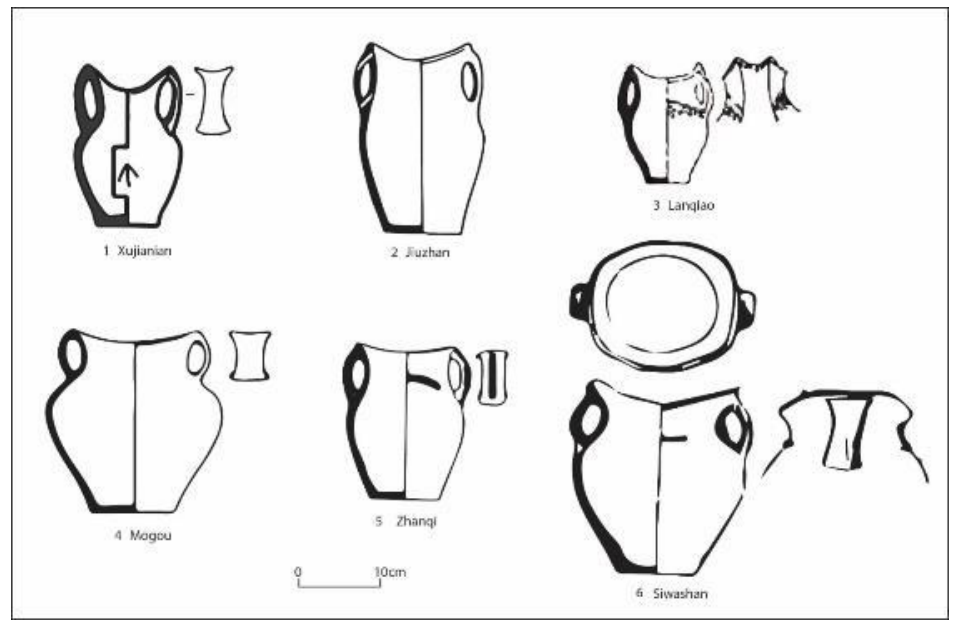

Figure 2 Siwa Ma'ankou jar types after: 1) Xujianian (Zhongguo 2006); 2) Jiuzhan (Wang and Shui 1997); 3) Lanqiao (Gansu et al. 1987); 4) Mogou (Gansusheng and Xibei 2014); 5) Zhanqi(Gansusheng 2012); 6) Siwashan (Xia, 1949) 


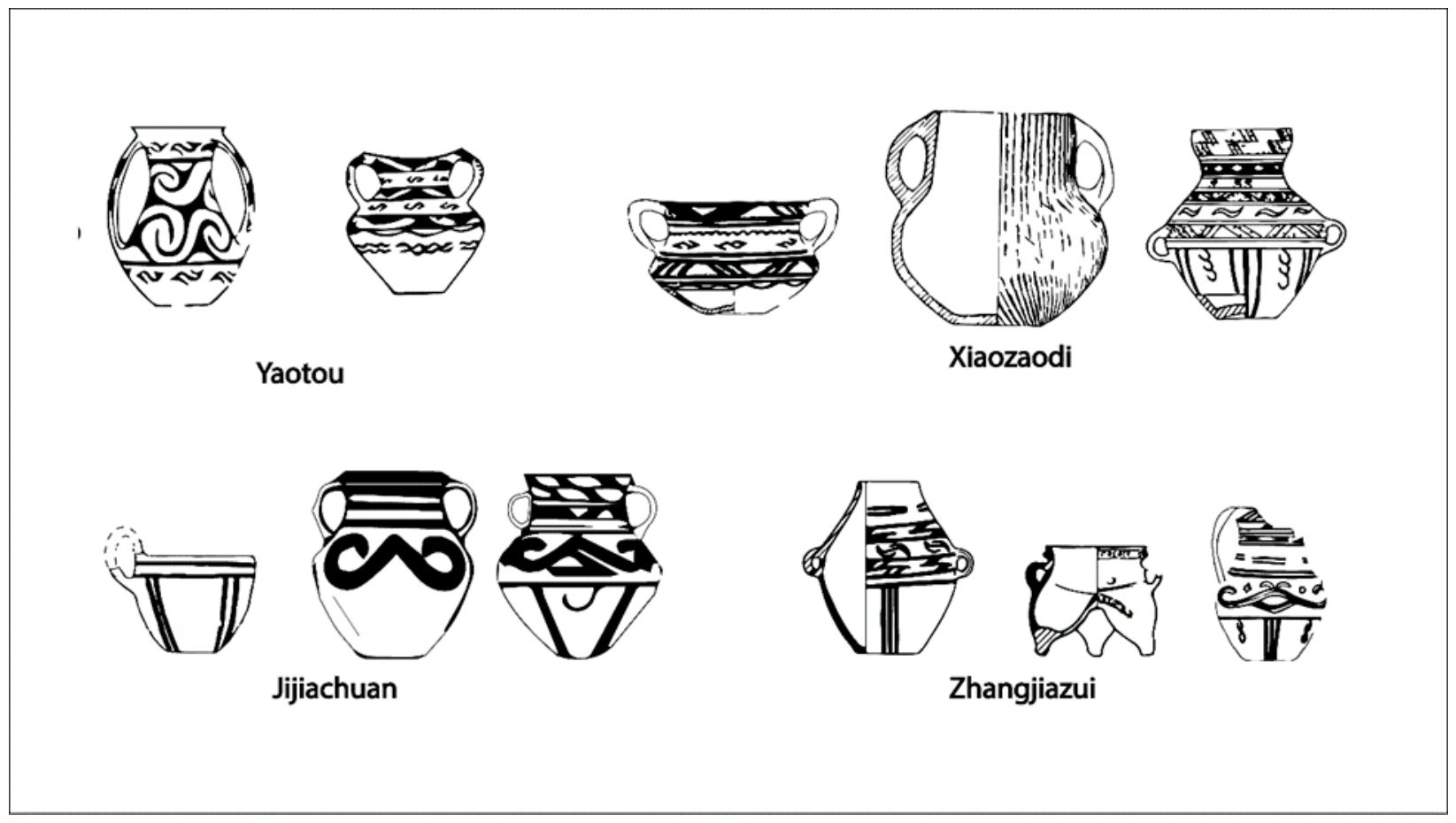

Figure 3 Xindian style ceramics (not drawn to scale) after 1) Yatou (Gansu 1981) 2) Xiaozaodi (Qinghai 1995) 3) Jijiachuan (Zhonguo 1980a) 4) Zhangjiazui (Zhongguo 1981a)

\section{Bibliography}

An C, Ji D, Chen F et al. (2010) Evolution of prehistoric agriculture in central Gansu Province, China: A case study in Qin'an and Li County. Chinese Science Bulletin 55: 1925-1930.

An C, Dong W, Li H et al. (2015) Variability of the stable carbon isotope ratio in modern and archaeological millets: evidence from northern China. Journal of Archaeological Science 53: 316-322.

An C, Tang L, Barton L et al. (2005) Climate change and cultural response around 4000 cal yr B.P. in the western part of Chinese Loess Plateau. Quaternary Research 63: 347-352.

An Z (1956) Gansu Yuangu wenhua jiqi youguan de jige wenti 甘肃远古文化及其有关的几个问题 [Some questions concerning the ancient cultures of Gansu]. Kaogu Tongxun 考古通讯 6: 9-19.

An Z (1999) The Bronze Age in Eastern Parts of Central Asia. In: Dani A and Masson V (eds) History of Civilizations of Central Asia. Delhi: Motilal Banarsidass Publishers, pp. 319-336.

Andersson J (1925) Preliminary report on archaeological research in Kansu. Memoirs of the Geological Survey of China (Series A) 5: 1-51.

Andersson J (1943) Researches into the prehistory of the Chinese. Stockholm: Museum of Far Eastern Antiquities.

Arbuckle B and Hammer E (2019) The Rise of Pastoralism in the Ancient Near East. Journal of Archaeological Research 27: 391-449.

Arz H, Lamy F and Patzöld P (2006). A pronounced dry event recorded around $4.2 \mathrm{ka}$ in brine sediments from the northern Red Sea. Quaternary Research 66(3): 432-441.

Atahan P, Dodson J, Li X et al. (2011) Subsistence and the isotopic signature of herding in the Bronze Age Hexi Corridor, NW Gansu, China. Journal of Archaeological Science 38: 1571-1582. 
Bai Wansong and Wu Hengxiang (1991) Leduxian Xinrenxiang Dafentan mudi diaocha 乐都县亲仁乡大坟 滩墓地调查 [Survey at the Dafentan cemetery, Qinren Village, Ledu County]. Qinghai wenwu 青海 文物 6:5-7.

Barton L, Newsome S, Chen F et al. (2009) Agricultural Origins and the Isotopic Identity of Domestication in Northern China. Proceedings of the National Academy of Sciences of the United States of America 106: 5523-5528.

Blaauw M (2012). Out of tune: the dangers of aligning proxy archives. Quaternary Science Reviews 36, 3849.

Bogaard A, Filipović D, Fairbairn A et al. (2017) Agricultural innovation and resilience in a long-lived early farming community: the 1,500-year sequence at Neolithic to early Chalcolithic Çatalhöyük, central Anatolia. Anatolian Studies 67: 1-28.

Bogaard A, Heaton T, Poulton P et al. (2007) The impact of manuring on nitrogen isotope ratios in cereals: archaeological implications for reconstruction of diet and crop management practices. Journal of Archaeological Science 34: 335-343.

Brosseder U and Miller B (2011) Xiongnu archaeology : multidisciplinary perspectives of the first steppe empire in Inner Asia, Bonn: Friedrich-Wilhelms-Universität Bonn.

Brunson K, Ren L, Zhao X et al. (2020). Zooarchaeology, ancient mtDNA, and radiocarbon dating provide new evidence for the emergence of domestic cattle and caprines in the Tao River Valley of Gansu Province, northwest China. Journal of Archaeological Science: Reports 31:102262.

Bunker E, Kawami T, Linduff K et al. (1997) Ancient bronzes of the eastern Eurasian steppes from the Arthur M. Sackler collections, New York: Arthur M. Sackler Foundation.

Butzer K and Endfield G (2012). Critical perspectives on historical collapse. Proceedings of the National Academy of Sciences of the United States of America 109, 3628-3631.

Carleton W and Collard M (2019). Recent Major Themes and Research Areas in the Study of HumanEnvironment Interaction in Prehistory. Environmental Archaeology 0, 1-17.

Chen X (2012) Hexi zoulang jiqi lingjin diqu zaoqi qingtong shidai yicun yanjiu 河西走廊及其邻近地区早 期青铜时代遗存研究 [Research on early Bronze Age remains in the Hexi Corridor and its neighboring regions]. PhD dissertation, Department of Archaeology, Jilin University, Changchun.

Chen H (2013) The Qijia Culture of the upper Yellow River valley. In Underhill A (ed.) A Companion to Chinese Archaeology. Malden, MA: Wiley-Blackwell, pp. 105-124.

Chen X, Fang Y, Hu Y et al. (2016) Isotopic Reconstruction of the Late Longshan Period (ca. 4200-3900 BP) Dietary Complexity before the Onset of State-Level Societies at the Wadian Site in the Ying River Valley, Central Plains, China. International Journal of Osteoarchaeology 26: 808-817.

Cheung C, Jing Z, Tang J et al. (2017a) Diets, social roles, and geographical origins of sacrificial victims at the royal cemetery at Yinxu, Shang China: New evidence from stable carbon, nitrogen, and sulfur isotope analysis. Journal of Anthropological Archaeology 48: 28-45.

Cheung C, Jing Z, Tang J et al. (2017b) Social Dynamics in Early Bronze Age China: A Multi-Isotope Approach. Journal of archaeological Science: Reports 16: 90-101.

Cheung C, Zhang H, Hepburn J et al. (2019) Stable isotope and dental caries data reveal abrupt changes in subsistence economy in ancient China in response to global climate change. PloS one 14: e0218943.

d'Alpoim Guedes J (2015) Rethinking the spread of agriculture to the Tibetan Plateau. Holocene 25(9): 1498-1510.

d'Alpoim Guedes J, Lu H, Hein A et al. (2015) Early evidence for the use of wheat and barley as staple crops on the margins of the Tibetan Plateau. Proceedings of the National Academy of Sciences of the United States of America 112 (18): 5625-30. 
Dai Bin (2014) Hetaozhuang Xiaohandi mudi yanjiu 核桃庄小旱地墓地研究 [Research on the Xiaohandi cemetery, Hetaozhuang]. Bianjiang kaogu yanniu 边疆考古研究 Research of China's Frontier Archaeology 1: 103-134.

DiCosmo N (2002) Ancient China and its enemies: the rise of nomadic power in East Asian history, Cambridge: Cambridge University Press.

Dittmar J, Berger E, Zhan X et al. (2019) Skeletal evidence for violent trauma from the bronze age Qijia culture (2,300-1,500 BCE), Gansu Province, China. International Journal of Paleopathology 27: 66-79.

Dodson J, Li X, Zhou X et al. (2013) Origin and spread of wheat in China. Quaternary Science Reviews 72: 108-111.

Dong G, Wang L, Cui Y et al. (2013a) The spatiotemporal pattern of the Majiayao cultural evolution and its relation to climate change and variety of subsistence strategy during late Neolithic period in Gansu and Qinghai Provinces, northwest China. Quaternary International 316: 155-161.

Dong G, Xin J, Robert E, et al. (2013b) Spatial and temporal variety of prehistoric human settlement and its influencing factors in the upper Yellow River valley, Qinghai Province, China. Journal of Archaeological Science 40 (5):2538-2546.

Dong G, Chen F, Wang H et al. (2014) Zhongguo Ganqing diqu Qijia wenhua shiqi nongye shuangxiang chuanbo 中国甘青地区齐家文化时期的农业双向传播 [Two-way transmission of agriculture during the Qijia culture period in Gansu and Qinghai, China]. In: Zhao H and Wang H(eds.) Zaoqi sichou zhilu ji zaoqi Qin wenhua guoji xueshu yantaohui lunwenji 早期丝绸之路暨早期秦文化国际 学术研讨会论文集 [Proceedings of the conference on the early Silk Road and the early Qin culture]. Beijing: Wenwu Chubanshe 文物出版社, pp. 134-137.

Dong G, Wang Z, Ren L et al. (2014) A Comparative Study of 14C Dating on Charcoal and Charred Seeds from Late Neolithic and Bronze Age Sites in Gansu and Qinghai Provinces, NW China. Radiocarbon 56 (1):157-163.

Fiskesjö M and Chen X (2004) China before China: Johan Gunnar Andersson, Ding Wenjiang, and the discovery of China's prehistory. Stockholm: Museum of Far Eastern Antiquities.

Flad R, Li S, Wu X et al. (2010) Early wheat in China: results from new studies at Donghuishan in the Hexi Corridor. The Holocene 20: 955-965.

Gansu Zangzu Zizhizhou Bowuguan (1994) Gansu Zhuoni Ya'er yizhi shijue jianbao 甘肃卓尼芉儿遗址试 掘简报 [Preliminary report on the test excavation conducted at the Ya'er site, Zhouni, Gansu Province]. Kaogu 考古 1994 (1): 13-22, 104.

Gansu Sheng Bowuguan Wenwu Gongzuodui (1981) Gansu Dongxiang Yatou Xindian wenhua muzang qingliji 甘肃东乡崖头辛店文化墓葬清理记 [Record of excavating Xindian culture graves at Yatou, Dongixang, Gansu]. Wenwu 文物 1981(2): 16-20.

Gansu Sheng Bowuguan (1960) Gansu gu wenhua yicun 甘肃古文化遗存 [The remains of ancient cultures in Gansu]. Kaogu xuebao 考古学报 1960 (2): 11-51.

Gansu Wenwu Gongzuodu, Beijing Daxue Kaoguxue and Xihexian Wenhuaguan (1987) Gansu he Lanqiao Siwa wenhua muzang 甘肃西和栏桥寺洼文化墓葬 [Siwa graves at Lanqiao, Xihe County, Gansu]. Kaogu 考古 1987 (8): 678-691, 770-772.

Gansu Sheng Wenwu Gongzuodui and Beijing Daxue Kaoguxi Gansu Shixizu (1988) Gansu Linxia Lianhuatai Xindian wenhua muzang fajue baogao 甘肅臨夏蓮花台辛店文化墓葬發掘報告 [Report on the excavation of Xindian culture graves at Lianhuatai, Linxia, Gansu]. Wenwu 文物 1988(3):7-20. 
Gansu Sheng Wenwu Kaogu Yanjiusuo and Gansusheng Bowuguan Lishibu (1994) Gansu Linxia Yanchang yizhi faxian de Xindian wenhua taoqi 甘肃临夏盐场遗址发现的辛店文化陶器 [Xindian culture ceramics discovered at Yanchang xite, Linxia, Gansu]. Kaogu yu wenwu 考古与文物 3:1-15.

Gansu Sheng Wenwu Kaogu Yanjiusuo and Xibei Daxue Sichou Zhilu Wenhua Yichan yu Kaoguxue Yanjiu Zhongxin (2014) Gansu Lintao Mogou mudi Siwa wenhua muzang 2009 nian fajue jianbao 甘肃临洮 墨勾墓地寺洼文化墓葬 2009 年发掘简报 [A preliminary report on the 2009 excavation season of the Siwa culture burials at Mogou, Lintao County, Gansu]. Wenwu 文物 2014 (6): 24-38

Gansu Sheng Wenwu Kaogu Yanjiusuo Zhongguo Guojia Bowuguan Beijing Daxue Kaogu Wenbo Xueyuan Shaanxisheng Kaogu Yanjiusuo and Xibei Daxue Weboxue (2008) Xihanshui shangyou kaogu diaocha baogao 西汉水上游考古调查报告 [Report on a survey conducted along the upper western Han River]. Beijing: Wenwu Chubanshe 文物出版社.

Gansu Sheng Wenwu Kaogu Yanjiusuo (2012) Gansu Minxian Zhanqi Siwa wenhua yizhi fajue jianbao 甘 肃岷县占旗寺洼文化遗址发掘简报 [Preliminary report on excavations conducted at the Zhanqi Siwa Culture site, Min County, Gansu]. Kaogu yu Wenwu 考古与文物 2012 (4): 35-47

Gao H, Zhu C and Xu W (2007) Environmental change and cultural response around 4200 cal. yr BP in the Yishu River Basin, Shandong. Journal of Geographical Sciences 17: 285-292.

Gao C and Wu P (1984). Qinghai Jingnei faxian de shiguanmu 青海境内发现的石棺墓 [Stone-cist graves discovered in Qinghai]. Qinghai kaogu xuehui huikan 青海考古学会会刊 1984(6): 4-12.

Goldsmith Y, Broecker W, Xu H et al. (2017) Northward extent of East Asian monsoon covaries with intensity on orbital and millennial timescales Proceedings of the National Academy of Sciences of the United States of America114: 1817-1821.

Guo Y, Mo D, Mao L et al. (2014) Settlement distribution and its relationship with environmental changes from the Paleolithic to Shang-Zhou period in Liyang Plain, China. Quaternary International 321: 2936.

He K, Lu H, Zhang J et al. (2017) Prehistoric evolution of the dualistic structure mixed rice and millet farming in China. Holocene 27: 1885-1898.

Hedges R and Reynard L (2007) Nitrogen isotopes and trophic level of humans in archaeology. Journal of Archaeological Science 34: 1240-1251.

Hein A and Stilborg O (2019) Ceramic production techniques and principles of raw material selection in prehistoric northwest China: a preliminary view based on material from the Museum of Far Eastern Antiquities, Stockholm. Journal of Archaeological Science: Reports 23: 104-115.

Hein A (2016) The Problem of Typology in Chinese Archaeology. Early China 39: 21-52.

Honeychurch W and Makarewicz C (2016) The Archaeology of Pastoral Nomadism. Annual Review of Anthropology 45: 341-359.

Hosner D, Wagner M, Chen X et al. (2016) Spatiotemporal distribution patterns of archaeological sites in China during the Neolithic and Bronze Age: An overview. Holocene 26: 1576-1593.

Hou G, Liu F, Liu C et al. (2009) Zhongquan xinshi Ganqing diqu guwenhua bianqian de huanding qudong [Prehistorical cultural transition forced by environmental change in the Mid-Holocene in the GansuQinghai region]. Dili xuebao 地理学报, 64: 54-58.

Hou, G, Lai Z, Sun Y et al. (2012) Luminescence and radiocarbon chronologies for the Xindian Culture site of Lamafeng in the Guanting Basin on the NE edge of the Tibetan Plateau. Quaternary Geochronology 10:394-398. 
Hu Q (1980) Shilun Siwa wenhua 试论寺洼文化 [A discussion of the Siwa culture]. Wenwu jikan 文物集 刊 1980 (2): 118-125.

Hu Y (2018) Thirty-Four Years of Stable Isotopic Analyses of Ancient Skeletons in China: an Overview, Progress and Prospects. Archaeometry 60: 144-156.

Huang C, Pang J, Zha X et al. (2011) Extraordinary floods related to the climatic event at 4200 a BP on the Qishuihe River, middle reaches of the Yellow River, China. Quaternary Science Reviews 30: 460-468.

Huanghe Shuiku Kaogudui Gansu Fendui (1959) Gansu Yongjingxian Zhangjiazui yizhi fajue jianbao 甘肃 永靖县张家咀遗址发掘简报 [Preliminary report of excavations conducted at Zhangjiazui site in Yongjingxian, Gansu]. Kaogu 考古 1959(4): 181-184.

Huelsemann F, Koehler K, Braun H et al. (2013) Human dietary $\delta(15) \mathrm{N}$ intake: representative data for principle food items. American Journal of Physical Anthropology 152: 58-66.

Izdebski A, Holmgren K, Weiberg E et al. (2016). Realising consilience: How better communication between archaeologists, historians and natural scientists can transform the study of past climate change in the Mediterranean. Quaternary Science Reviews, 136, 5-22.

Jaang L (2015) The Landscape of Chinas Participation in the Bronze Age Eurasian Network. Journal of World Prehistory 28: 179-213.

Jaffe Y (2020) A Grave matter - Linking pastoral economies and identities in the Upper Xiajiadian culture (1200-600 BCE), China, World Archaeology, Online first.

Jaffe Y (2016) The Continued Creation of Communities of Practice - Finding Variation in the Western Zhou Expansion (1046-771 BCE). PhD dissertation, Cambridge: Harvard University.

Jaffe $Y$ and Flad R (2018) Prehistoric Globalizing Processes in the Tao River Valley, Gansu, China? In: Boivin $\mathrm{N}$ and Frachetti $\mathrm{M}$ (eds) Globalization in Prehistory Contact, Exchange, and the 'People Without History'. Cambridge: Cambridge University Press, pp 131-161.

Jaffe Y, Bar-Oz G and Ellenblum R (2019) Improving integration in societal consequences to climate change.

Proceedings of the National Academy of Sciences of the United States of America 116, 4755.

Jaffe $\mathrm{Y}$, Castellano L, Shelach-Lavi G et al. (Forthcoming). Mismatches of scale in the Application of Paleoclimatic Research to Chinese Archaeology. Quaternary Research.

Jaffe $Y$, Hein A, Womack A et al. (accepted) Complex pathways towards emergent pastoral settlements New research on the Bronze Age Xindian culture of Northwest China. Journal of World Prehistory

Jia D, Li Y and Fang X (2018) Complexity of factors influencing the spatiotemporal distribution of archaeological settlements in northeast China over the past millennium. Quaternary Research 89: 413-424.

Jones J and Britton K (2019) Multi-scale, integrated approaches to understanding the nature and impact of past environmental and climatic change in the archaeological record, and the role of isotope zooarchaeology. Journal of Archaeological Science: Reports 23: 968-972.

Jones S, Fleitmann D and Black S (2016). A critical evaluation of the 4.2 ka BP event using new highresolution evidence from stalagmites in the Middle East. Geophysical Research Abstracts. Vol. 18, EGU2016: 582.

Jun C (2004) Zaoqi Zhongguo wenming: Zhouyuan wenhua yu Xizhou wenming 早期中国文明: 周原文 化与西周文明 [Early Chinese civilizations: Zhouyuan wulture and the Western Zhou civilization]. Jiangsu: Jiaoyu Chubanshe 教育出版社.

Kintigh K and Ingram S (2018) Was the drought really responsible? Assessing statistical relationships between climate extremes and cultural transitions. Journal of Archaeological Science 89, 25-31. 
Lee G, Crawford G, Liu L, et al. (2007) Plants and People from the Early Neolithic to Shang Periods in North China. Proceedings of the National Academy of Sciences of the United States of America 104: 10871092.

Li F (2006) Landscape and power in early China: the crisis and fall of the Western Zhou, 1045-771 BC, Cambridge: Cambridge University Press.

Li F, Li S and Shui T (1993) Huluhe liuyu de gu wenhua yu gu huanjing 葫芦河流域的古文化与古环境 [Ancient cultures and environment in the Hulu River Valley]. Kaogu 考古 1993 (9):822-42.

Li J, Han L, Zhang G et al. (2017) Temporal-spatial variations of human settlements in relation to environment change during the Longshan culture and Xia-Shang periods in Shanxi Province, China. Quaternary International 436: 129-137.

Li S, Shui T and Wang H (2010). Hexi zoulang shiqian kaogu diacha baogao 河西走廊史前考古调查报告 [The Hexi corridor prehistoric survey report]. Kaogu Xuebao 考古學報 2010 (2): 229-264.

Li T, Wu Y, Mo D et al. (2014) Holocene environmental change and its influence on the prehistoric culture evolution and the formation of the Taosi site in Linfen basin, Shanxi province, China. Quaternary International 349: 402-408.

Li X, Dodson J, Zhou X et al. (2007) Early cultivated wheat and broadening of agriculture in Neolithic China. The Holocene 17: 555-560.

Li Y, Wang, N, Zhou X et al. (2014). Synchronous or asynchronous Holocene Indian and East Asian summer monsoon evolution: a synthesis on Holocene Asian summer monsoon simulations, records and modern monsoon indices. Global and Planetary Change, 116:30-40.

Liu F and Feng Z (2012) A dramatic climatic transition at $\sim 4000$ cal. yr BP and its cultural responses in Chinese cultural domains. The Holocene 22: 1181-1198.

Liu F, Zhang Y, Feng Z et al. (2010) The impacts of climate change on the Neolithic cultures of GansuQinghai region during the late Holocene Megathermal. Journal of Geographical Sciences 20: 417-430.

Liu L (2000) The development and decline of social complexity in northern China: some environmental and social factors. Indo-Pacific Prehistory Association Bulletin 4: 14-3.

Liu X, O'Connell T, Lightfoot E et al. (2014) From necessity to choice: dietary revolutions in west China in the second millennium BC. World Archaeology 46: 661-680.

Lu G (2013) Luguo quan Jing, Luo Weihe shangyou Xizhou wenhua bianjie ji xiangguan wenti chutan 路国 权泾、洛、渭河上游西周文化边界及相䏌问题初论 [A preliminary discussion of the cultural borders of the Western Zhou culture and related issues in the upper reaches of the Jing, Luo, and Wei Rivers]. Kaogu yu wenwu 考古与文物 2013 (3): 48-56.

Ma M, Dong G, Jia X et al. (2016) Dietary shift after 3600 cal yr BP and its influencing factors in northwestern China: Evidence from stable isotopes. Quaternary Science Reviews 145: 57-70.

Ma M, Dong G, Lightfoot E et al. (2014) Stable isotope analysis of human and faunal remains in the western Loess Plateau, approximately 2000 cal BC. Archaeometry 56: 237-255.

Maher B (2008). Holocene variability of the East Asian summer monsoon from Chinese cave records: a reassessment. The Holocene 18(6): 861-866.

Makarewicz C and Sealy J (2015) Dietary reconstruction, mobility, and the analysis of ancient skeletal tissues: expanding the prospects of stable isotope research in archaeology. Journal of Archaeological Science 56: 146-158.

Makarewicz C (2016) Toward an integrated isotope zooarchaeology. In: Grupe G and McGlynn G (eds.) Isotopic Landscapes in Bioarchaeology. Berlin: Springer pp. 189-209.

Marom N, Meiri M, Tepper Y et al. (2019) Zooarchaeology of the social and economic upheavals in the Late Antique-Early Islamic sequence of the Negev Desert. Scientific Reports 9: 1-10. 
Mayewski P, Rohling E, Stager J et al. (2004). Holocene climate variability. Quaternary Research 62: 243255.

McCoy M (2017) Geospatial Big Data and archaeology: Prospects and problems too great to ignore. Journal of Archaeological Science 84: 74-94.

Minhexian Bowuguan (2015) Qinghai Minhexian Lajia yizhi de Xindian wenhua muzang 青海民和县喇家 遗址的辛店文化墓葬 [The Xindian culture graves at Lajia site, Minhe County, Qinghai]. Kaogu 考古 2015(3): 115-120.

Nakamura A, Yokoyama Y, Maemoku H et al. (2016) Weak monsoon event at 4.2 ka recorded in sediment from lake rara, Himalayas. Quaternary International, 397:349 - 35.

Nan Y (1989) Xindian wenhua xulie jiqi Kayue, Siwa wenhua de guanxi 辛店文化序列及其与卡约、寺洼 文化的全系. In: Yu Weichao 俞伟超 (ed) Kaogu leixingxue de lilun yu shixian 考古类型学的理论与 实践. Beijing: Wenwu Chubanshe 文物 出版社 pp. 73-109.

Paasche $\varnothing$ and Bakke J (2009) The Holocene Turnover-a global climate shift at 4 ka. Geophysical Research Abstracts 11, EGU 2009: 14-17.

Pearson J, Haddow S, Hillson S et al. (2016) Stable carbon and nitrogen isotope analysis and dietary reconstruction through the life course at Neolithic Catalhoyuk, Turkey. Journal of Social Archaeology 15: $210-232$.

Pei Z (1987) Gansu Liqian Kaogu Baogao 甘肃史前 考古报告. In Pei W (ed) Liqian Kaoguxue Lunwenji 裴 文中史前考古学论文集 Beijing: Wenwu Chubanshe 文物出版社, pp. 208-255.

Qinghaisheng Wenwu Guanlichu Kaogudui and Zhongguo Shehui Kexueyuan Kaogu Yanjiusuo (1984) Qinghai Liuwan: Ledu Liuwan Yuanshi Shehui Mudi 青海柳湾——乐都柳湾原始社会墓地 [Qinghai Liuwan: primitive society cemetery at Ledu Liuwan]. Beijing: Wenwu Chubanshe 文物出版社.

Qinghaisheng Wenwu Guanlisuo (1995) Qinghai Minhe Hetaozhuang Xiaohandi mudi fajue jianbao 青海 民和核桃小旱地墓地发掘简报 [Preliminary report of excavations conducted at Xiaohandi cemetery, Hetaozhuang, Minhe, Qinghai]. Kaogu yu wenwu 考古与文物 1995(2): 1-12.

Qinghaisheng Wenwu Kaogu Yanjiusuo, Sichuan Daxue Lishi Wenhua Xuehuan, and Lajia Yizhi Bowuguan (2019) Qinghai Minhexian Lajia yizhi 2015-2016 nian Xindian wenhua yicun fajue jianbao 青海民和 县喇家遗址 2015 ～ 2016 年辛店文化遗存发掘简报 [Excavation report of Xindian culture remains excavated at Lajia site, Minhe County, Qinghai, in 2015-2016]. Kaogu 考古 6:3-14.

Railsback L, Liang F, Brook G et al. (2018) The timing, two-pulsed nature, and variable climatic expression of the 4.2 ka event: A review and new high-resolution stalagmite data from Namibia. Quaternary Science Reviews, 186:78-90.

Rawson J (2013) Ordering the Exotic: Ritual Practices in the Late Western and Early Eastern Zhou. Artibus Asiae 5: 5-76.

Ren L, Li X, Kang L et al. (2017) Human paleodiet and animal utilization strategies during the Bronze Age in northwest Yunnan Province, southwest China. PLOS ONE 12, e0177867.

Ren R (2016) Xibei diqu caitao wenhua yanjiu 西北地區彩陶文化研究 [Study on the Painted-Pottery Culture of Northwest Culture]. PhD dissertation Changchun: Jilin University.

Ren R (2017) Lun Lajia yizhi “Xindian wenhua” muzang de wenhua guishu 论喇家遗址“辛店文化”墓葬的 文化归属 [On the cultural ownership of the “Xindian culture" graves at Lajia site]. Kaogu 考古 2017(5): 114-120. 
Ren Ruibo (2019) Lun Xindian wenhua de fenqi yu niandai 论辛店文化的分期与年代 [On the periodization and date of the Xindian culture]. Kaogu xuebao 考古學報 2019(4):439-460.

Rousseau D, Zanchetta G, Weiss H et al. (2019). The 4.2 ka BP climatic event. Climate Past, 15, 1665-1676. Selbitschka A (2018) The Pitfalls of Second-hand Information: On the Traditionalist Dogma in Chinese Excavation Reports. Bulletin of the Museum of far Eastern Antiquities, 79/80:31-72.

Shelach G (2009) Prehistoric societies on the northern frontiers of China: archaeological perspectives on identity formation and economic change during the first millennium BCE, London; Oakville, CT: Equinox Pub.

Shui T (2001) Zhongguo xibei diqu qingtong shidai kaogu lunji 中國西北地區青銅時代考古論集 [Papers on the Bronze Age Archaeology of Northwest China], Beijing: Kexue Chubanshe 科學出版社.

Su K and Kidder T (2019) Humans and climate change in the middle and lower Yellow River of China, Quaternary International, 521:111-117.

Tan Z, Han Y, Cao J et al. (2018) The linkages with fires, vegetation composition and human activity in response to climate changes in the Chinese Loess Plateau during the Holocene. Quaternary International, 488: 18-29.

Thomas R and Miller H (2018). Zooarchaeology and Stable Isotopes. In: López Varela SL (ed.) The Encyclopedia of Archaeological Sciences. Berlin: Springer pp. 1-6.

Wagner M, Hosner D, Fleck A et al. (2013) Mapping of the spatial and temporal distribution of archaeological sites of northern China during the Neolithic and Bronze Age. Quaternary International 290-291: 344-357.

Wang H (2012) Gansu diqu xinshiqi-qingtongqi shidai kaoguxue wenhua de puxi yu geju 甘肃地区新石器 - 一青铜器时代考古学文化的谱系与格局. Kaoguxue yanjiu 考古學研究 (2012): 210-243.

Wang X, Fuller B, Zhang P et al. (2018) Millet manuring as a driving force for the Late Neolithic agricultural expansion of north China. Scientific Reports 8: 1-9.

Wang Z and Shui T (1997) Gansu Heshui Jiuzhan yizhi fajue baogao 甘肃合水九站遗址发掘报告 [Excavation report of the Jiuzhan site in Heshui, Gansu Province]. Kaoguxue yanjiu 考古学研究 1997 (3): 300-549.

Wanner H, Solomina O, Grisjean M et al. (2011) Structure and origin of Holocene cold events. Quaternary Science Review: 30: 3109-3123.

Wenwu Bianji Weiyuanhui (ed.) (1979) Wenwu kaogu gongzuo sanshi nian 文物考古工作三十年 [Thirty years of archaeological research]. Beijing: Wenwu Chubanshe 文物出版社.

Womack A, Jaffe Y, Zhou J et al. (2017) Mapping Qijiaping: New Work on the Type-Site of the Qijia Culture (2300-1500 B.C.) in Gansu Province, China. Journal of Field Archaeology 42: 488-502.

Wu W and Liu T (2004) Possible role of the "Holocene Event 3" on the collapse of Neolithic Cultures around the Central Plain of China. Quaternary International 117: 153-166.

Xia N (1949) Lintao Siwashan fajue ji 临洮寺洼山发掘记 [Excavation record of Siwashan, Lintao]. Zhongguo kaogu xuebao 中国考古学报: 71-187.

Xia N (1961) Kaoguxue lunwenji 考古學論文集 [Collected archaeological essays], Beijing: Kexue Chubanshe 科學出版社.

Xie D (1985) Lüelun Xindian wenhua 略論辛店文化 [Preliminary discussion of the Xindian culture]. Wenwu ziliao congkan 文物資料叢刊 1985: 59-76. 
Xie D (2002) Ganqing diqu shiqian kaogu 甘青地区史前考古 [Prehistoric archaeology of Gansu and Qinghai], Beijing: Wenwu Chubanshe 文物出版社.

Xoplaki E, Fleitmann D and Luterbacher J (2016) The Medieval Climate Anomaly and Byzantium: A review of the evidence on climatic fluctuations, economic performance and societal change. Quaternary Science Reviews, 136, 229-252.

Xu X (1988) Shilun Kayue wenhua de leixing yu fenqi 试论卡约文化的类型与分期 (The Typology and Periodization of the Kayue Culture). Qinghai wenwu 青海文物 1988 (1): 10-14.

Yan W (1978) Gansu caitao de yuanliu 甘肅彩陶的源流 [The origin of painted pottery]. In: Yan W (ed) Yangshao wenhua yanjiu 仰韶文化研究 [Research on the Yangshao culture]. Beijing: Wenwu Chubanshe 文物出版社, pp. 309-327.

Yang Y (2013). Minxian Zhanqi Siwa wenhua mudi yanjiu 岷縣占旗寺窪文化墓地研究 (A Study of the Siwa Culture Cemetery in Zhanqi Shi, Minxian). PhD disseration Xian: Northwest University.

Yang Y, Ren L, Dong G et al. (2019) Economic Change in the Prehistoric Hexi Corridor (4800-2200 BP), North-West China. Archaeometry 61: 957-976.

Zhang D, Jim C, Lin G et al. (2006) Climatic Change, Wars and Dynastic Cycles in China Over the Last Millennium. Climatic Change 76: 459-477.

Zhang $\mathrm{H}$, Cheng $\mathrm{H}$, Cai $\mathrm{Y}$ et al. (2018). Hydroclimatic variations in southeastern China during the $4.2 \mathrm{ka}$ event reflected by stalagmite records, Climate Past 14, 1805-1817.

Zhang Y, Huang C, Pang J et al. (2018) Identification of the prehistoric catastrophes at the Lajia Ruins using micromorphological analysis within the Guanting Basin, Minhe County, Qinghai Province. Archaeological and Anthropological Sciences 10: 711-723.

Zhao H (1989) Gansu dongbu Qin he Qiang Rong wenhua de kaoguxue tansuo 甘肃东部秦和姜戎文化的 考古学探索 [An archaeological exploration of the Qin and Qiang Rong cultures in eastern Gansu]. In: Yu W (ed.) Kaogu leixingxue de lilun yu shixian 考古类型学的理论与实践 [Theory and practice of archaeological typology]. Beijing: Wenwu Chubanshe 文物出版社, pp. 145-176.

Zhongguo Shehui Kexueyuan Kaogu Yanjiusuo Gansu Gongzuodui (2006) Xujianian Siwa wenhua mudi 徐 家碾寺洼文化墓地 [Excavation Report of the Siwa Culture Xujialian Cemetery]. Beijng: Kexue Chubanshe 科学出版社.

Zhongguo Shehui Kexuyuan Kaogu Yanjiusuo Gansu Gongzuodui (1980a) Gansu Yongjing Zhangjiazui yu Jijiachuan yizhi de fajue 甘肃永靖张家咀与姬家川遗址的发掘 [Excavations at Zhangjiazui and Jijiachuan sites in Yongjing, Gansu]. Kaogu xuebao 考古学报 (2):187-220.

Zhongguo Shehui Kexuyuan Kaogu Yanjiusuo Gansu Gongzuodui (1980b) Gansu Linxia Lianhuatai Xindian wenhua yizhi 甘肅臨夏蓮花台辛店文化遺址 [The Lianhuatai Xiandian culture site, Linxia, Gansu]. Kaogu 考古 1980 (4):296-310.

Zhongguo Shehui Kexuyuan Kaogu Yanjiusuo (1999) Shizhaocun yu Xishanping 师赵村与西山坪 [Shizhaocun and Xishanping]. Beijing: Zhongguuo Dabaike Quanshu Chubanshe 中国大百科全书出 版社.

Zhou L and Garvie-Lok S (2015) Isotopic evidence for the expansion of wheat consumption in northern China. Archaeological Research in Asia 4: 25-35. 
